\title{
Physicochemical characters of oilseeds from selected mustard genotypes
}

\author{
R. H. Sharif, R. K. Paul ${ }^{1^{*}}$, D. K. Bhattacharjya and K. U. Ahmed \\ Department of Biochemistry, Sher-e-Bangla Agricultural University, Dhaka-1207, Bangladesh \\ ${ }^{1}$ Department of Chemistry, Pabna University of Science and Technology (PUST), Pabna-6600, Bangladesh \\ *E-mail: ratanpaul05@yahoo.com
}

\begin{abstract}
To evaluate the physicochemical characteristics of oilseeds, three varieties of mustard oilseeds were studied their seed weight, moisture, ash, carbohydrate, protein, fat, total energy and minerals composition of oil and cake. Among the varieties the highest thousand grain weight was found in BARI Sarisha-17 $(4.24 \mathrm{~g})$ and the lowest thousand grain weight was found in BARI Sarisha-15 (3.17 g). The highest moisture content was observed from BARI Sarisha-15 (4.52\%); whereas the lowest moisture content was found in BARI Sarisha-17 (4.10\%). The variety BARI Sarisha-17 contained significantly highest amount of oil (41.98\%) whereas the variety BARI Sarisha-16 contained lowest amount of oil (40.95\%). BARI Sarisha-16 contained highest amount of ash (14.20\%). Significantly highest amount of protein was obtained from BARI Sarisha-15 (28.00\%) and the lowest amount of protein obtained from BARI Sarisha-17 (22.57\%). BARI Sarisha-17 contained highest amount of carbohydrate (18.85\%), whereas BARI Sarisha-15 contained the lowest amount of carbohydrate (13.73\%). BARI Sarisha-16 contained highest amount of Ca (2.52\%) and $\mathrm{Zn}(66.80 \%)$. BARI Sarisha-15 contained highest amounts $\mathrm{Cu}(13.40 \%)$ and Fe (170.30\%). Mustard varieties contained erucic acid (51.35-50.67\%). Highest amount of total saturated fatty acid (TSFA) contained in BARI Sarisha$15(9.02 \%)$ and the lowest amount contained BARI Sarisha-16 (8.28\%). Highest amount of total unsaturated fatty acid (TUSFA) contained in BARI Sarisha-17 (90.26\%) lowest amount contained in BARI Sarisha-16 (87.04\%). The highest amount of gross energy found from BARI Sarisha-15 (543.60 kcal/g; while lowest amount of gross energy recorded from BARI Sarisha-16 (531.20 kcal/g). Highest saponification value found in BARI Sarisha-17 (159.40) and lowest saponification value was found in BARI Sarisha-15 (157.6). The result of this research work confirms the mustard varieties seed to be of good quality and can be used for food preparation. The knowledge of this study could be utilized for various food preparation and selection for breeding purpose.
\end{abstract}

Keywords: Mustard, Grain weight, Mineral content, Fatty acid, lodine value

\section{Introduction}

Oilseed crops have occupied an important place in human nutrition as they remain the major sources of calories and proteins for a large proportion of the world population. Oilseeds are those seeds that contain considerably large amounts of oil. The most commonly known oilseeds (conventional oilseeds) are groundnut, soybean, palm kernel, cotton seed, olive, sunflower seed, rapeseed, sesame seed, linseed, safflower seed, etc (Ajala et al., 2014; Aremu et al., 2006). Generally, oils and fats from seeds and nuts constitute an essential parts of man's diet. The chief important of the vegetable oils lies in their food value. Vegetable oils derived from plant seeds have been playing vital roles to provide comfort in human lives in various aspects, they are essential in meeting global nutritional demands are utilized for many food and other industrial purposes (Idouraine et al., 1996). In a balanced diet for human health $20-25 \%$ of calories should come from oils and fats. Herbal oils are the main sources of fats and fat-soluble vitamins, which have a substantial role in the human diet (Stuchlik et al., 2002). After cereals, oily seeds are the second food sources throughout the world, whose oil is of rich fatty acid types (Siavash et al., 2005).

Mustard seeds have been highly prized medicinal as well as culinary spice being in use since ancient times. The seeds are obtained from mustard plant (Brassica spp.) which also include cabbage, broccoli, brussels sprouts, etc. Mustard seeds have high energy content, having $28-32 \%$ oil with relatively high protein content (28-36\%). Well refined mustard oil has a yellow to brown color and its smell and taste are enjoyable. Mustard oil has a special fatty acid composition: $20-28 \%$ oleic acid, $10-12 \%$ linolic, $9.0-9.5 \%$ linolenic acid and 30-40\% erucic acid (Abul-Fadl et al., 2011). The protein quality and quantity of $B$. campestries obtained oil cake is high (Chowdhury et al., 2014). Mustard seeds contain $28-32 \%$ protein by weight, although these values can vary slightly between varieties, growing regions and crop years. The amino acid composition of mustard protein is well balanced; it is rich in essential amino acids. Rapeseed 
and mustard contain relatively lower amount carbohydrate. It consists mainly glucose, sucrose and fructose crude fiber, dry mustard seeds contained $20-23 \%$ carbohydrate. Mustards seed are rich source of many health benefiting minerals such as calcium, manganese, copper, iron, selenium, and zinc (Sarwar et al., 2009). Mustard seeds act as a laxative, stimulant to gastric mucosa and increase intestinal secretion (Sarwar et al., 2009; Sarwar et al., 2004). These crops, including rape (B. campestris L., and B. napus $L$.) and mustard (B. juncea) are the third major source of edible vegetable oils in the world, after soybean and oily palm. The residue left after oil extraction (i.e., oil cake or meal) being rich in protein can be used as livestock feed (Durrani et al., 1990).

Oilseed is critically needed in many developing countries where protein-energy malnutrition remains a major health hazard, especially among children. The protein quantity and quality, caloric value, and overall nutrient content of oilseeds are quite good. Some oil seed cultivars viz. BARI Sarisha-15, BARI Sarisha-16, BARI Sarisha-17, is widely cultivated throughout the country. If the nutritional status of oil seed is known, their consumption and multipurpose uses will be increased. The characteristics of oils from different sources depend mainly on their compositions and no oil from a single source can be suitable for all purposes, thus the study of their constituents is important. Hence the physicochemical properties of these popular selected varieties was undertaken to ensure their nutritional status. The main purpose of our present study is to determine the oil content, protein, carbohydrate and minerals content of different genotypes groundnut seed.

\section{Material and Methods}

\section{Materials and Measurement}

The experiment was carried out at the Biochemistry laboratory of the Department of Biochemistry, Sher-eBangla Agricultural University, Dhaka, Bangladesh and Post Harvest Technology Division BARI Joydebpur, Gazipur, Bangladesh. Three varieties of mustard (Brassica spp.) namely BARI Sarisha-15 (grain properties is yellow in color, oval in shape and small in size), BARI Sarisha-16 (grain properties is brownish in color and round in shape and large size), BARI Sarisha-17 (grain properties is brownish in color, round in shape and large size) were collected from the Oilseeds Research Centre of BARI, Gazipur, Bangladesh. Seed were cleaned sun dried and stored into plastic container in a cool place until used for the chemical analysis. The nutritive value of a food-grain is indicated by its composition shown by chemical analysis. The degree to which the chemical analysis indicates the nutritive value is dependent on the constituents determined. All the chemicals used were collected from Merck (Germany), Wako Pure Chemicals Industries Ltd. and JHD (China). These chemicals were used analytical and spectroscopic grade without further purification.

\section{Determination of Physical Properties of Mustard Varieties}

Determination of grain weight: Grain weight was determined by randomly selecting thousand seed sample weighted by electric balance (KEY: JY-2003; China).

Determination of moisture: Moisture content of mustard sample was determined by a thermostat controlled oven. Empty aluminum moisture dish was weighted $\left(\mathrm{W}_{1}\right)$ and $2.5 \mathrm{~g}$ sample was taken in a moisture dish and weighted $\left(\mathrm{W}_{2}\right)$. The sample was spread evenly and placed without lid in oven and dried samples overnight at $100{ }^{\circ} \mathrm{C}$ temperature. The dishes were transferred to desiccators to cool. Aluminum dish was weighed after cooling $\left(\mathrm{W}_{3}\right)$. The percentage of the moisture was then calculated by the following formula.

$\%$ Moisture $=\frac{w_{2}-w_{3}}{w_{2}-w_{1}} \times 100$

Determination of ash: The sample is ignited at $600{ }^{\circ} \mathrm{C}$ by muffle furnace (Nebertherm: Mod-L9/11/c6; Germany) to burn off all organic material. The inorganic material which does not volatilize at that temperature is called ash. The temperature of the muffle furnace was fixed to $600{ }^{\circ} \mathrm{C}$ and crucible was heated for $1 \mathrm{~h}$ and transferred into desiccators; cooled them to room temperature and weighted $\left(\mathrm{W}_{1}\right)$. 
About $2 \mathrm{~g}$ sample was put into the crucible weighted $\left(\mathrm{W}_{2}\right)$. The sample was burned in a muffle furnace at $600{ }^{\circ} \mathrm{C}$ for about $2 \mathrm{~h}$. The crucibles were transferred into the desiccators and cooled them to room temperature and weighted $\left(\mathrm{W}_{3}\right)$. It was done immediately to prevent moisture absorption. The incineration repeated until constant weight was obtained. The percentage of the ash was then calculated by the following formula (Ranganna et al., 1986).

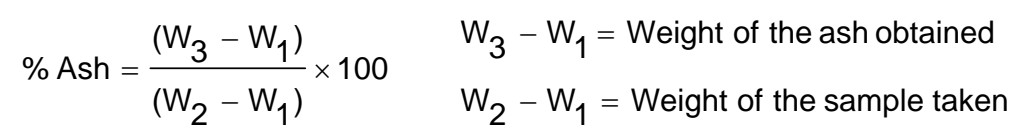

\section{Determination of Chemical Constant of Mustard Varieties}

Estimation of fatty acid composition: Fatty acid composition was determined by gas-liquid chromatographic method (Uppstrom et al., 1978). About $12 \mathrm{mg}$ of oil or equivalent amount of oil seeds was taken (seed was crushed in an oil paper and then transferred into a test tube). The sample was extracted and transesterified at the same time with $5 \mathrm{ml}$ ethylated reagent (petroleum ether/0.02M sodium hydroxide in ethanol (2/3) and shake. The samples were kept for overnight at room temperature. $10 \mathrm{ml}$ salt solution ( $80 \mathrm{~g} \mathrm{NaCl}$ and $3 \mathrm{~g}$ sodium hydrogen sulphate in 1 liter water) was added and shake. As soon as the two layers were separated, the benzene phase was transferred to small test tubes. A Philips PU 4500 chromatograph instrument was used with flame ionization detector (FID). A glass column (1.5m $x 4 \mathrm{~mm}$ ) was packed with BDS. With this column the injection post, column and detector temperature was set at $220{ }^{\circ} \mathrm{C}, 185^{\circ} \mathrm{C}$ and $240{ }^{\circ} \mathrm{C}$, respectively. Nitrogen flow (used as career gas) rate was $22 \mathrm{ml} / \mathrm{min}$, the injection volume was $2 \mu$ l. Peak areas were measured with an electronic digital integrator (Shinadzu C-R6A chromatopac).

Saponification value: At first, $2 \mathrm{~g}$ fat was taken in $250 \mathrm{ml}$ round bottom flask and $25 \mathrm{ml}, 0.5 \mathrm{~N}$ alcoholic potassium hydroxide solution added in same flask. The flask was fitted with a long air condenser and heated solution at reflux temperature about 30 minutes. Finally, the flask was cooled and added $1 \mathrm{ml}$ of $1 \%$ phenolphthalein solution and titrate the excess of the alkali against standard $0.5 \mathrm{~N} \mathrm{HCl}$ acid. At the same time and under similar conditions carry out a blank titration without fat $(25 \mathrm{ml}, 0.5 \mathrm{~N}$ same alcoholic $\mathrm{KOH}$ solution was taken in another round bottom flask and heated in a similar way and titrated, against $0.5 \mathrm{~N}$ acid). $1 \mathrm{ml}$ of $0.5 \mathrm{~N} \mathrm{HCl}$ acid was equivalent to $0.02805 \mathrm{~g}$ of $\mathrm{KOH}$.

Saponification value $=\frac{(b-a) \times 0.02805 \times 1000}{\text { Wt. of substance ing }} \times 100$

Where, $\mathrm{a}=\mathrm{mL}$ of $0.5 \mathrm{~N}$ acid required in sample solution titration

$\mathrm{b}=\mathrm{mL}$ of $0.5 \mathrm{~N}$ acid required in blank solution titration

lodine value: $5 \mathrm{~g}$ of oil or fat was taken into $200 \mathrm{ml}$ a glass stoppard bottle. $5 \mathrm{ml}$ of $\mathrm{CCl}_{4}$ was added to dissolve this oil after $25 \mathrm{ml}$ of Wij's solution was added and to allow it at least 1 hour in a dark place. Then $5 \mathrm{ml}$ of $10 \%$ potassium iodide solution and $50 \mathrm{ml}$ water were added to each bottle and titrated against 0.1 $\mathrm{N} \mathrm{Na} \mathrm{S}_{2} \mathrm{O}_{3}$ solution using starch solution as the indicator, near the end point of titration the color of solution becomes pale yellow. Blue color disappears which indicates the end point. At the same time and under similar conditions carry out a blank titration without oil or fat.

lodine value $=\frac{100}{\text { Wt. of oil }} \times 10.0127 \times\left(v_{1}-v_{2}\right)$

Where, $\mathrm{a}=\mathrm{mL}$ of $0.1 \mathrm{~N} \mathrm{Na}_{2} \mathrm{~S}_{2} \mathrm{O}_{3}$ used in blank titration

$\mathrm{b}=\mathrm{mL}$ of $0.1 \mathrm{~N} \mathrm{Na}_{2} \mathrm{~S}_{2} \mathrm{O}_{3}$ used in the case of oil titration

Estimation of carbohydrate: Total carbohydrate estimation method was described by Raghuramulu et al., 2003. The content of the available carbohydrate was determined by the following equation:

Carbohydrate $=100-[($ Moisture + Protein + Ash + Oil/Fats $)$ g/100 g] 


\section{Chemical analyses}

Estimation of oils/fats: The oil content was determined by the ether soluble extract method. Dried sample was weighed out into an extraction thimble. Weight of thimble and sample were recorded in laboratory book. The thimble was placed into the soxhlet. $100 \mathrm{ml}$ ethyl ether was added to the soxhlet flask then it was connected to holder and condenser. Soxhlet flask was placed on hot plate and distilled at low temperature for 20 hours. After extraction it was turned off and allowed to cool. When distillation was ceased, the extraction thimble was removed and allowed to air dry for 40 minutes the thimble was weighed out. The fat determined by the above procedure contains usual lipids including waxes pigments, certain gums and resins (Thiex et al., 2003). A better name for these constituents would be "ether soluble extract."

$\%$ Crude fats/oil (on a dry weight basis) $=$

Wt. of thimble \& sample before extraction - Wt. of thimble \& sample after

Weitht of sample before extraction

Estimation of total protein content by microkjeldhal method: The protein content of food stuff is obtained by estimating the nitrogen content of the material and multiplying the nitrogen value by 5.5 (according to the fact that nitrogen constitutes on average 18\% of a protein molecule). The estimation of nitrogen is done by Kjeldhal method (AOAC, 2010) which depends upon the fact that organic nitrogen when digested at $380^{\circ} \mathrm{C}$ temperature with sulphuric acid in the presence of catalyst selenium oxide, mercury or copper sulfate is converted into ammonium sulphate (AOAC, 2010). Ammonia liberated by making the solution alkaline is distilled into a known volume of a standard acid which is then back titrated. A known quantity of the finely ground sample $(100 \mathrm{mg})$ weighted out in an Mkj digestion flask. About $2 \mathrm{~g}$ digestion mixture (100 g of $\mathrm{K}_{2} \mathrm{SO}_{4}$ was thoroughly mixed with $20 \mathrm{~g}$ of $\mathrm{CuSO}_{4} .5 \mathrm{H}_{2} \mathrm{O}$ and $2.5 \mathrm{~g}$ selenium dioxide was added with it) was added with it $2 \mathrm{ml}$ of concentrated sulphuric acid was dispensed into the flask. Then it was digested for about $2 \mathrm{hrs}$ at $380^{\circ} \mathrm{C}$ temperature in Mkj digestion set and was cooled the clear digest. The digest was dissolved in minimum amount of distilled water and carefully transferred to an Mkj distillation set $60 \%, 10 \mathrm{ml}$ of $\mathrm{NaOH}$ solution was added and distilled it. The distillate was collected for 5 min into $4 \%, 5 \mathrm{ml}$ boric acid containing 2 drops of mixed indicator (methyl red and bromocresol green) in a $50 \mathrm{ml}$ conical flask, till the color of solution was changed. The distillate was titrated against a standard $0.02 \mathrm{~N} \mathrm{HCl}$ acid and noted the titer value (TV).

$$
\mathrm{N} \%=\frac{(14.007) \times(\text { Normality of the Acid, } 0.02) \times(\text { Titer volume })}{\text { Weight of sample }(\mathrm{mg})} \times 100
$$

Where, 14.007 is the equivalent weight of nitrogen

Nitrogen \% is converted into protein by multiplying with a factor 5.5 for cereals and pulses.

Crude protein $(\%)=\% \mathrm{~N} \times 5.5$

\section{Estimation of minerals}

Mineral content was determined using absorption spectrophotometer.

Reagent for $\mathrm{Ca}$ and $\mathrm{Mg}$ determination: $1 \%$ lanthanum solution: $59 \mathrm{~g}$ of lanthanum oxide $\left(\mathrm{La}_{2} \mathrm{O}_{3}\right)$ were added with about $50 \mathrm{ml}$ of water. Slowly and cautiously, $250 \mathrm{ml}$ concentrated $\mathrm{HCl}$ was added to dissolve the $\mathrm{La}_{2} \mathrm{O}_{3}$. It was made to 5 liters with water.

Preparation of standards solution: For convenience the $\mathrm{Cu}$, Fe and $\mathrm{Zn}$ were prepared together in water. The high concentration for these elements was as follows: $2 \mu \mathrm{g} \mathrm{Cu} / \mathrm{ml}, 10 \mu \mathrm{g} \mathrm{Fe} / \mathrm{ml}, 4 \mu \mathrm{g}$ and $2 \mu \mathrm{g}$ $\mathrm{Zn} / \mathrm{ml}$. Ca and $\mathrm{Mg}$ were prepared in the same solution with high concentrations as follows; $100 \mu \mathrm{g} \mathrm{Ca} / \mathrm{ml}$, $40 \mu \mathrm{g} \mathrm{Mg} / \mathrm{ml}$.

Digestion solution: Nitric-perchloric solution. Concentrated perchloric acid (100 ml) was added to $500 \mathrm{ml}$ concentrated $\mathrm{HNO}_{3}$ to prepare nitric-perchloric solution. 


\section{Digestion of oilseed cake for determination of $\mathrm{Ca}, \mathrm{Mg}$, Fe and $\mathrm{Zn}$}

Digestion procedure: Weighted $500 \mathrm{~g}$ dry seed sample and put into a $50 \mathrm{ml}$ boiling flask. $5 \mathrm{ml}$ of nitricperchloric solution was allowed on cool hot plate and turned temperature to $375^{\circ} \mathrm{C}$. It was allowed to digest for 1 hour and 30 minutes. The flask was removed from digestion chamber and was cooled and 15 $\mathrm{ml}$ water was added. The flask was agitated and heated to dissolve the ash and filter.

Analytical procedure: By using a combination diluter-dispenser, $1 \mathrm{ml}$ aliquot was taken from filtrate and $19 \mathrm{ml}$ water (dilution 1 ) was added. The other dilutions were made in the following order. For $\mathrm{P}, \mathrm{K}$ and $\mathrm{Na}$ determination, $1 \mathrm{ml}$ aliquot from dilution $1,9 \mathrm{ml}$ of water and $10 \mathrm{ml}$ of color reagent were mixed together. It was allowed to stand about 20 minutes and reading was taken of spectrophotometer at $680 \mathrm{~nm}$. For Ca and $\mathrm{Mg}$ determination, $1 \mathrm{ml}$ aliquot from dilution $1,9 \mathrm{ml}$ of water and $10 \mathrm{ml}$ of $1 \%$ lanthanum solution were mixed together. It was analyzed by absorption spectrophotometer. For $\mathrm{Fe}, \mathrm{Mn}$ and $\mathrm{Zn}$ determination, the original filtrate was used to analyze these elements by absorption spectrophotometer.

\section{Estimation of energy}

The chemical energy content of food ingredients is usually expressed in terms of heat units (since all forms of energy are convertible into heat energy). The gross food energy was estimated by multiplying the crude protein, crude fat and total carbohydrate by at water factors 4,9 and 4 respectively (Onimawo et al., 1998; Osborne et al., 1998).

\section{Statistical analysis}

The recorded data for each character from the experiments was analyzed statistically find out the variation resulting from experimental treatments using MSTAT package program. The mean for all the treatments were calculated and analysis of variance of characters under the study was performed by $\mathrm{F}$ variance test. The mean differences were evaluated by least significance difference test.

\section{Results and Discussion}

Three varieties of mustard seed were collected for the determination of physical and chemical characteristics.

\section{Physical characteristics of mustard varieties}

Grain weight: Seed weights were determined at $13 \%$ moisture level. Seed weight varied with their size and shape (Table 1). BARI Sarisha-17 seed size is higher than the other two varieties mustard. Among different mustard varieties highest thousand grain weight was found in BARI Sarisha-17 (4.24 g), followed by BARI Sarisha-16 (3.620 g) and BARI Sarisha-15 (3.17 g). Our studies mustard seed grain weight are consistent with the results reported by Chowdhury et al., (2014) Banga et al., (2013), Siddiqui et al., (2004), Andarhennadi et al., (1991), Biswas (1989), Chowdhury et al., (1987) and Kaul et al., (1986). Banga et al., (2013) and Siddiqui et al., (2004) found that the highest amount of 1000 seed weight were $5.15 \mathrm{~g}$ and $3.95 \mathrm{~g}$, respectively. Our studies mustard seed grain weight values are higher than the reported value of Mandal et al., (2002); who found that thousand seed weight varies from 2.50-2.65 g.

Moisture: The moisture content of different released varieties of mustard was ranged from $4.10 \%$ to $4.52 \%$ (Table 1). The results of the moisture content were significantly lower than Sarker et al., (2015), Mahmud et al., (2012), BARI annual report (1987-88). According to Sarker et al., (2015) moisture content of mustard cakes were $9.20 \pm 0.5 \%$; and the moisture content $8.3 \pm 0.2 \%$ reported in literature by Mahmud et al., (2012).

Table 1. Weight of $\mathbf{1 0 0 0}$ seeds and moisture of different varieties of mustard oilseed varieties

\begin{tabular}{c|cc}
\hline $\begin{array}{c}\text { Name of the Varieties } \\
\text { (Treatments) }\end{array}$ & Weight of 1000 Seeds (at 13\% Moisture Level) (g) & Moisture (\%) \\
\hline BARI Sarisha-15 & 3.17 & $4.52 \mathrm{a}$ \\
BARI Sarisha-16 & 3.62 & $4.20 \mathrm{~b}$ \\
BARI Sarisha-17 & 4.24 & $4.10 \mathrm{~b}$ \\
\hline LSD (0.05) & 2.627 & 0.3285 \\
CV (\%) & $1.33 \%$ & $3.36 \%$ \\
\hline
\end{tabular}

Figure in a column followed by a common letter do not differ significantly at $5 \%$ level by DMRT 


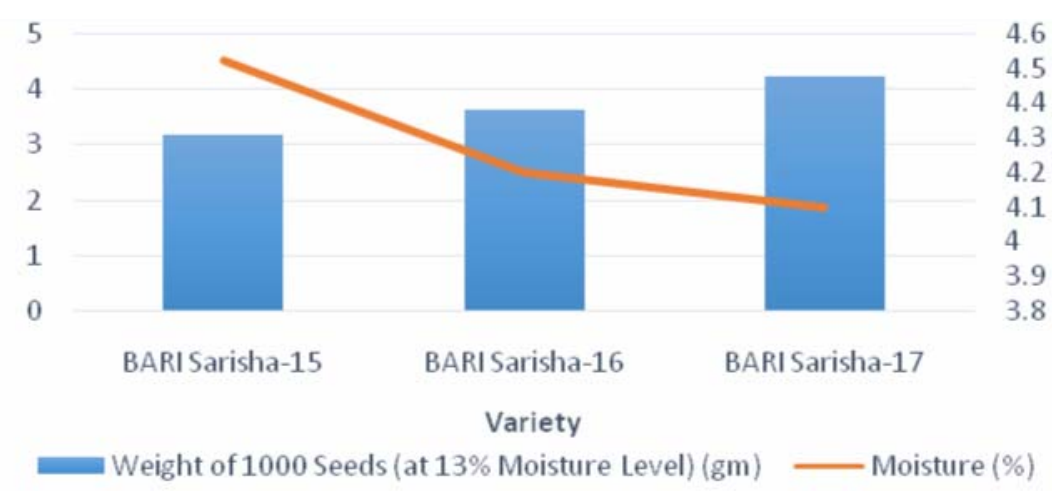

Fig.1. Relation between weight of 1000 seeds in $\mathrm{g}$ (at $13 \%$ moisture level) and moisture of different varieties of mustard oilseed.

Oil content: The oil content of different varieties of mustard varied from $40.95 \%$ to $49.51 \%$ (Table 2). Mustard variety BARI Sarisha-17 contained highest amount of oil (41.98\%), followed by BARI Sarisha-15 (41.85\%) and BARI Sarisha-16 (40.95\%). The results clearly indicated that mustard variety can be considered as better source of oil. Present studies values of oil content mustard seed are higher than the reported value of Gadei et al., (2012) and B. R. Moser et al. (2009), who found that oil content ranges from 28-32\%; whereas Arif et al. (2012), Bhowmik (2003), Novoselov et al., (1994) reported that oil content of rapeseed ranges from $45.67-43.87 \%, 42-46 \%$ and $45-46 \%$ respectively, which are slightly higher than present results. On the other hand, the present investigations were more or less similar the reported values of Vijay et al., (1992), Rathore (1999-2000), BARI report (2001), Sengupta et al., (2003), Mandal et al., (2002). These variations might be due to biological factor, environmental factor, soil and crop management practices.

Oil cake: The BARI Sarisha-16 contained significantly highest amount of oil cake $(59.05 \%)$, followed by BARI Sarisha-15 (58.15\%) and BARI Sarisha-17 (58.02\%) (Table 2). The present studies values of mustard oil cake were supported by the reported values of Chowdhury et al., (2014) and Appelqvist et al., (1992). Chowdhury et al., (2014) found that percentage of oil cake range from 58.14 to 59.95\% and Appelqvist et al., (1992), reported that typically rape seed oil (kind of mustard seed) contain 58\% cake.

\section{Dry weight of cake}

The highest value was obtained from BARI Sarisha-16 (54.85\%), followed by BARI Sarisha-17 (53.92) and BARI Sarisha-15 (53.63\%) (Table 2).

Table 2. Proximate analysis of oil content, oil cake and dry wt. of cake of the different oilseed varieties

\begin{tabular}{l|c|c|c}
\hline $\begin{array}{c}\text { Name of the Varieties } \\
\text { (Treatments) }\end{array}$ & Oil Content (\%) & Oil Cake (\%) & Dry Wt. of Cake (\%) \\
\hline BARI Sarisha-15 & $41.85 \mathrm{c}$ & $58.15 \mathrm{~b}$ & $53.63 \mathrm{c}$ \\
BARI Sarisha-16 & $40.95 \mathrm{~d}$ & $59.05 \mathrm{a}$ & $54.85 \mathrm{a}$ \\
BARI Sarisha-17 & $41.98 \mathrm{c}$ & $58.02 \mathrm{~b}$ & $53.92 \mathrm{~b}$ \\
\hline LSD (0.05) & 0.1726 & 0.1726 & 0.1908 \\
CV (\%) & $0.21 \%$ & $0.17 \%$ & $0.21 \%$ \\
\hline
\end{tabular}

Figure in a column followed by a common letter do not differ significantly at $5 \%$ level by DMRT 


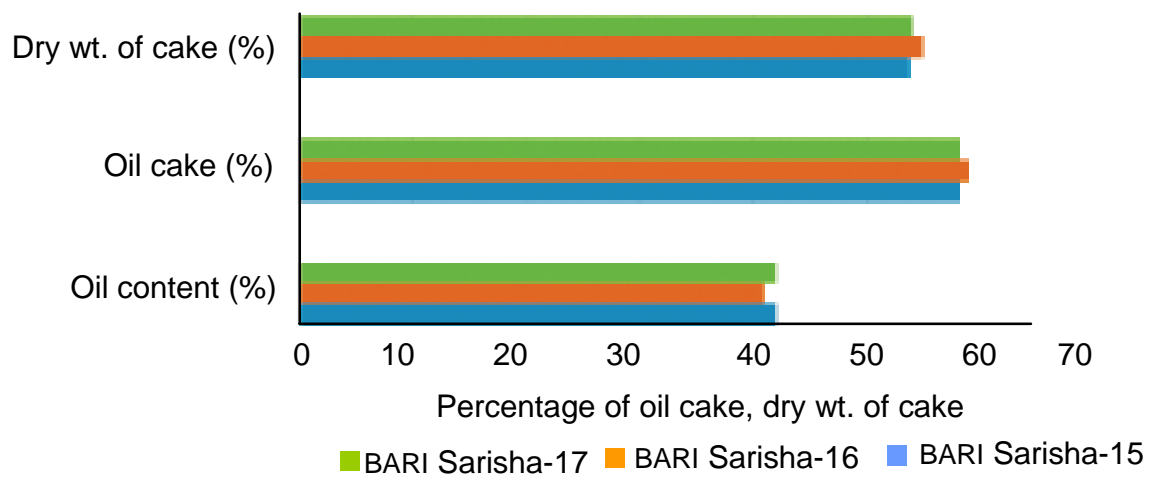

Fig. 2. Relation between oil content, oil cake and dry wt. of cake of different mustard oilseed varieties.

\section{Chemical characteristics of mustard varieties}

\section{Chemical constant of oil}

Saponification value: Saponification values of different varieties of mustard varied have been presented in Table 3. The highest saponification values of mustard variety was found in BARI Sarisha-17 (159.40), the lowest value was found in BARI Sarisha-15 (157.60) and BARI Sarisha-16 was found 157.90. These values are supported by Chowdhury et al., (2014) study. Our present studies saponification values found in mustard varieties are lower than the various reported studies as Khan et al., (2013), Martin et al., (1995) and Richet et al. (1987). They were found saponification value of the extracted mustard oils $>170$, 170 and 182.4 respectively.

lodine value: The iodine values of different varieties of mustard varieties have been presented in Fig. 3 . In case of mustard varieties, the all iodine values are statistically similar BARI Sarisha-15 (72.50), BARI Sarisha-16 (70.60) and BARI Sarisha-17 (73.44) (Table 3). The observed values were supported by the reported values of Chowdhury et al., (2014), Khan et al., (2013), Richet et al., (1987), Martin et al., (1995) and Chowdhury et al., (2015).

\section{Table 3. Chemical constant of oil of different mustard oilseed varieties}

\begin{tabular}{c|c|c}
\hline $\begin{array}{c}\text { Name of the varieties } \\
\text { (Treatment) }\end{array}$ & $\begin{array}{c}\text { Saponification } \\
\text { Value }\end{array}$ & Iodine Value \\
\hline BARI Sarisha-15 & 157.60 & 72.50 \\
BARI Sarisha-16 & 157.90 & 70.60 \\
BARI Sarisha-17 & 159.40 & 73.44 \\
LSD (0.05) & 2.35 & 3.28 \\
CV (\%) & $0.66 \%$ & $2.00 \%$ \\
\hline
\end{tabular}

Figure in a column followed by a common letter do not differ significantly at $5 \%$ level by DMRT 


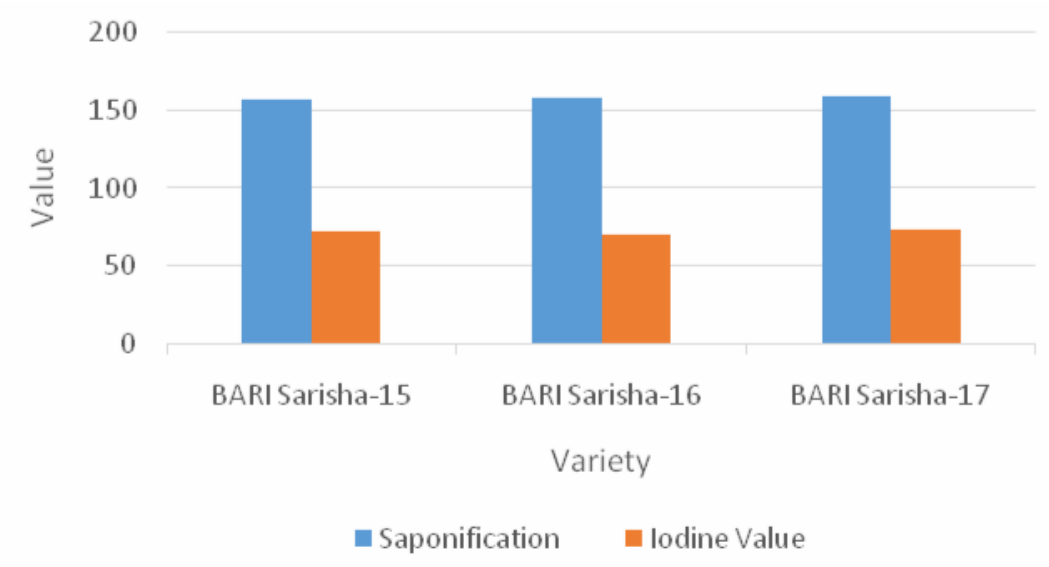

Fig. 3. Saponification value and iodine value of different mustard oilseed varieties.

Fatty acid composition: There was a significant difference between the studied mustard varieties in terms of their fatty acid composition (Table 4). Significantly the highest amount of palmitic acid was observed in BARI Sarisha-17 (3.22\%). Lowest amount of palmitic acid content was observed in BARI Sarisha-16 (2.09\%) and BARI Sarisha-15 was observed in 2.88\% palmitic acid. Highest amount of stearic acid content found in BARI Sarisha-15 (1.40\%) and the lowest amount found in BARI sarisha-17 (1.19\%). BARI Sarisha-17 contained the highest amount of oleic acid $18.69 \%$ followed by BARI Sarisha-15 (16.16\%) and BARI Sarisha-16 (14.72\%). The BARI Sarisha-15, BARI Sarisha-16, BARI Sarisha-17, contained $4.74 \%, 4.96 \%, 4.02 \%$ of arachidic acid respectively; these three varieties contained statistically similar amount of arachidic acid. Highest amount of linoleic acid was found in BARI Sarisha-15 (15.11\%) which was significantly highest among all the varieties and lowest amount was found BARI Sarisha-17 (14.38\%). The linoleic acid content is important from the stand point of utilization of oil for food products. Mustard variety BARI Sarisha-17, BARI Sarisha-16, BARI Sarisha-15 contained $51.35 \%, 50.67 \%$ and $50.67 \%$ of erucic acid respectively. Concentration of linoleic acid varied from $0.240 \%$ to $7.10 \%$. Analytical data indicated that the highest amount of total saturated fatty acid (TSFA) contained in BARI Sarisha-15 (9.02\%) and the lowest amount contained BARI Sarisha-16 (8.28\%). Highest amount of total unsaturated fatty acid (TUSFA) contained in BARI Sarisha-17 (90.26\%) lowest amount contained in BARI Sarisha-16 (87.04\%). The highest amount of gross energy found from BARI Sarisha-15 (543.60 kcal/g); while lowest amount of gross energy recorded from BARI Sarisha-16 $(531.20 \mathrm{kcal} / \mathrm{g})$. From the present data, it might be suggested that the mustered oil seeds are suitable for edible purpose as they contained higher amount of protein, oil and gross energy. These findings are in conformity with the results by Chowdhyry et al., (2014), Moser et al., (2009), Appelqvist (1980), Chowdhury et al., (2015), Mubashir (2012), Abul-fadl et al., (2011), Chauhan and Kumar (2011). Mubashir, (2012) stated that mustard oil possess $42 \%$ erucic acid and 12\% oleic acid, it has also 6\% omega-3 alpha-linolenic acid and 15\% omega-6 linoleic acid along with $12 \%$ saturated fats.

Chauhan and Kumar, (2011), observed that the concentration of oleic acid (18:1), a beneficial monounsaturated fatty acid, ranges from $3.6-32.2 \%$ in rapeseed-mustard oil. Abul-fadl et al., (2011) reported that, erucic acid was in yellow and brown mustard seeds oils were represented about $37.89 \%$ and $23.90 \%$, respectively. Oleic acid was ranged from $19.08 \%$ to $20.24 \%$ of total fatty acid profiles in both yellow and brown mustard oilseeds. Moreover, linoleic acid was recorded from 12.37 to 21.36 both yellow and brown mustard oilseeds. Moser et al., (2009) observed that, mustard oil has a special fatty acid composition, it contains about 20-28\% oleic acid, 10-12\% linoleic, 9.0-9.5\% linolenic acid, and 30-40\% erucic acid. Moreover, Appelqvist (1980) found that fatty acid composition of mustard varieties i.e., 3.0\%, $0.8 \%, 9.9 \%, 13.5 \%, 9.8 \%, 6.3 \%$ and $52.3 \%$ for palmitic acid, stearic acid, oleic acid, linoleic acid, linolenic acid, eicosenoic acid and erucic acid, respectively. 
Table 4. Fatty acid composition of the different oilseed varieties

\begin{tabular}{c|c|c|c|c|c|c|c}
\hline \multirow{2}{*}{$\begin{array}{c}\text { Name of the } \\
\text { Varieties } \\
\text { (Treatments) }\end{array}$} & \multicolumn{9}{c}{ Percentage of Fatty Acids } \\
\cline { 2 - 8 } & \multicolumn{2}{|c|}{ Saturated Fatty Acid (SFA) } & \multicolumn{3}{c}{ Unsaturated Fatty Acid (USFA) } \\
\cline { 2 - 8 } & $\begin{array}{c}\text { Palmitic } \\
\text { Acid }\left(\mathrm{C}_{16: 0}\right)\end{array}$ & $\begin{array}{c}\text { Stearic } \\
\text { Acid }\left(\mathrm{C}_{18: 0}\right)\end{array}$ & $\begin{array}{c}\text { Arachidc } \\
\text { Acid } \\
\left(\mathrm{C}_{20: 0}\right)\end{array}$ & $\begin{array}{c}\text { Oleic } \\
\text { Acid } \\
\left(\mathrm{C}_{18: 1}\right)\end{array}$ & $\begin{array}{l}\text { Linoleic } \\
\text { Acid } \\
\left(\mathrm{C}_{18: 2}\right)\end{array}$ & $\begin{array}{c}\text { Linolenic } \\
\text { Acid } \\
\left(\mathrm{C}_{18: 3}\right)\end{array}$ & $\begin{array}{l}\text { Erucic } \\
\text { Acid } \\
\left(\mathrm{C}_{22: 1}\right)\end{array}$ \\
\hline BARI Sarisha-15 & $2.88 \mathrm{e}$ & $1.40 \mathrm{~d}$ & $4.74 \mathrm{a}$ & $16.16 \mathrm{e}$ & $15.11 \mathrm{c}$ & $7.14 \mathrm{a}$ & $50.6 \mathrm{~b}$ \\
BARI Sarisha-16 & $2.09 \mathrm{f}$ & $1.23 \mathrm{e}$ & $4.96 \mathrm{a}$ & $14.72 \mathrm{f}$ & $14.88 \mathrm{~cd}$ & $6.84 \mathrm{~b}$ & $50.6 \mathrm{~b}$ \\
BARI Sarisha-17 & $3.22 \mathrm{~d}$ & $1.19 \mathrm{e}$ & $4.02 \mathrm{a}$ & $18.69 \mathrm{~d}$ & $14.38 \mathrm{~d}$ & $5.84 \mathrm{c}$ & $51.35 \mathrm{a}$ \\
\hline LSD (0.05) & 0.1409 & 0.09965 & 1.987 & 1.005 & 0.6904 & 0.2573 & 0.5548 \\
CV (\%) & $1.12 \%$ & $2.99 \%$ & $39.33 \%$ & $1.52 \%$ & $1.62 \%$ & $3.59 \%$ & $1.20 \%$ \\
\hline
\end{tabular}

Figure in a column followed by a common letter do not differ significantly at $5 \%$ level by DMRT

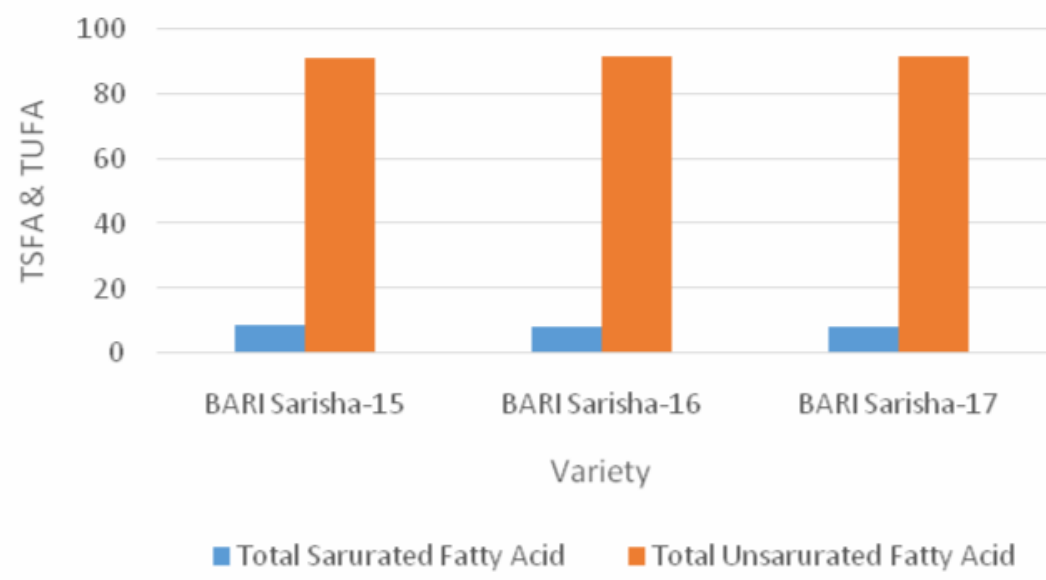

Fig. 4. Percentage of total saturated and unsaturated fatty acid of oil of the different varieties of oilseed.

\section{Analysis of oil cake}

After extraction of oil, the seeds gave the defatted cakes of varying amounts. The results of cake analysis were presented in Table 5.

Ash: Ash content of different released varieties of mustard oilseeds were variable and ranged from $11.90 \%$ to $14.20 \%$ (Table 5). BARI Sarisha-16 contained the highest amount of ash (14.20\%) followed by BARI Sarisha-17 (12.50\%) and BARI Sarisha-15 (11.90\%). Our studies values of mustard varieties were significantly higher than the reported value of Sarker et al., (2015), Abul-Fadl et al., (2011), Sosulski et al., (1991) and Kaul et al., (1986).

Protein: Protein content of different varieties of mustard has been presented in Table 5 . Significantly highest amount of protein was obtained from BARI Sarisha-15 (28.00\%), the lowest amount of protein content found in BARI Sarisha-17 (22.57\%). The present studies values are more or less similar with the reported values of Sarker et al., (2015), Chowdhury et al., (2010), Sosulki et al., (1991), and Mirza et al., (1998), Chowdhury et al., (2015). These results are lower than those reported by many other authors. Prapakornwiriya and Diosady (2004) determined the protein $45.0 \%$ and $34.0 \%$ respectively. Sengupta et al. (2003) revealed that protein content of rapeseed were ranges from 44.2-44.7\%. However our studies result is higher than the reported value of many other authors of Asibuo et al., (2008), Ingale et al., (2011), Ayoola et al., (2012). This might be due to the nitrogen fertilizer application, ecology and agronomics practices. 
Carbohydrate: Carbohydrate content of different released varieties of oil seed were determined moisture free basis. The data have been presented in Table 5. The amount of carbohydrate contained found in BARI Sarisha-17, BARI Sarisha-16, BARI Sarisha-15 were 18.85\%, 14.05\%, 13.75\% respectively. Agronomics practices, environmental factors as well as variation among the species and varieties might be influenced the carbohydrate content. Our studies carbohydrate content are slightly lower than the reported values of Ayoola et al., (2012), Bachheti et al., (2012) and Gopalan et al., (1981). Bachheti et al., (2012) found that mustard seeds contain $23.8 \%$ carbohydrate and Gopalan et al., (1981) stated that dry mustard seeds contained $20-23 \%$ carbohydrate.

Table 5. Proximate analysis of protein, ash and carbohydrate content of the different oilseed varieties (dry weight basis)

\begin{tabular}{c|c|c|c}
\hline $\begin{array}{c}\text { Name of the varieties } \\
\text { (Treatments) }\end{array}$ & Ash (\%) & Protein (\%) & $\begin{array}{c}\text { Carbohydrate } \\
(\%)\end{array}$ \\
\hline BARI Sarisha-15 & $11.90 \mathrm{c}$ & $28.00 \mathrm{c}$ & $13.73 \mathrm{~b}$ \\
BARI Sarisha-16 & $14.20 \mathrm{a}$ & $26.60 \mathrm{c}$ & $14.05 \mathrm{~b}$ \\
BARI Sarisha-17 & $12.50 \mathrm{~b}$ & $22.57 \mathrm{~d}$ & $18.85 \mathrm{a}$ \\
\hline LSD $(0.05)$ & 0.2636 & 1.661 & 1.953 \\
CV (\%) & $1.29 \%$ & $3.10 \%$ & $10.10 \%$ \\
\hline
\end{tabular}

Figure in a column followed by a common letter do not differ significantly at $5 \%$ level by DMRT

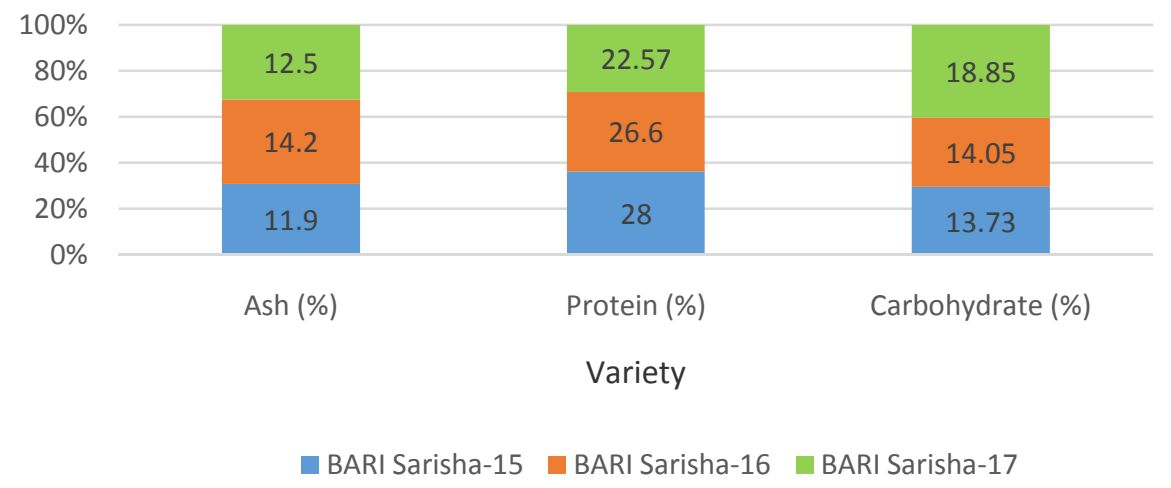

Fig. 5. Proximate analysis of protein, ash and carbohydrate content of the different oilseed varieties (dry weight basis).

\section{Proximate analysis of minerals content of the different oilseed varieties}

Different major and minor minerals were analyzed this work. The amounts of major minerals content of rapeseed have been illustrated in Table 6. It is well known that rape seed contained small amount of minerals.

In case of calcium content of different released varieties of mustard was ranged from $2.58 \%$ to $1.10 \%$ (Table 6). Significantly highest amount of calcium (Ca) content was observed in BARI Sarisha-16 (2.52\%), followed by BARI Sarisha-15 (2.15\%); these varieties are statistically similar in respect to calcium content. The lowest amount of calcium content was obtained from BARI Sarisha-17 (1.10\%). The present investigations were supported by reported value of Sarker et al., (2015), Sengupta et al., (2003), Chowdhury et al., (2015), Bachheti et al., (2012), Josefson (1988), and Pathak et al., (1973). Sengupta et al., (2003) and Bachheti et al., (2012), reported that mustard contains $492.1 \mathrm{mg}$ and $490 \mathrm{mg}$ calcium respectively, while Josefson (1988) stated that mustard contain $0.7 \% \mathrm{Ca}$.

Magnesium is the major minerals for human nutrition. Magnesium content of different released varieties of oil seed have been presented in Table 6 . There is no significant variation in magnesium content among the varieties. Magnesium content of different varieties was ranged from $0.64 \%$ to $0.740 \%$. The present investigations were supported by reported value of Sarker et al., (2015), Sengupta et al., (2003), Chowdhury et al.,(2015), Bachheti et al., (2012), Josefson (1988), and Pathak et al., (1973). 
Percentage of nitrogen is influenced by nitrogen fertilizer application, ecology and agronomies practices. Significantly highest amount of nitrogen content was obtained from BARI Sarisha-15 (4.48\%), the lowest amount of nitrogen content found in BARI Sarisha-17 (3.67\%) (Table-6). The present studies values are more or less similar with the reported values of Sarker et al., (2015), Sosulki et al., (1991), Chowdhury et al., (2010), and Mirza et al. (1998).

Copper contained of different varieties of mustards were ranged from 6.18-13.40 ppm (Table 6). Statistically similar amount of $\mathrm{Cu}$ content observed in BARI Sarisha-15 (13.40 ppm), BARI Sarisha-16 (13.26 ppm). Lowest amount of $\mathrm{Cu}$ contained observed in BARI Sarisha-17 (6.18 ppm). Our studies investigations were supported by reported value of Sarker et al., (2015), Arif et al., (2012), Bachheti et al., (2012), Josefson (1988), and Pathak et al., (1973).

Iron contained of different varieties of mustard was ranged from $75.70 \mathrm{ppm}$ to $170.30 \mathrm{ppm}$ (Table 6). Significantly highest amount of Fe contained was observed in BARI Sarisha-15 (170.30 ppm) which was followed by BARI Sarisha-17 (100.70 ppm). However these results were supported by the reported values of Chowdhury et al., (2015). These might be influenced the different levels of $\mathrm{Fe}$ in soil, fertilizer and variation among the varieties. Our studies Fe values were higher than the reported values of Bachheti et al., (2012) and Josefson (1988); who found that Fe content of mustard seed oil were $8.11 \mathrm{~g} / 100 \mathrm{~g}$ and 18 ppm respectively.

The zinc content of different varieties of mustard was ranged from 51.45 to $66.80 \mathrm{ppm}$ in (Table 6). Significantly highest amount of $\mathrm{Zn}$ contained was found in BARI Sarish-16 (66.80 ppm) which was followed by BARI Sarish-17 (51.91 ppm). The lowest amount was found in BARI Sarish-15 (51.45 ppm). The present values were supported by the reported value of Chowdhury et al., (2015), Bachheti et al., (2012) and Josefson (1988).

Table 6. Proximate analysis of minerals content of the different oilseed varieties

\begin{tabular}{c|c|c|c|c|c|c}
\hline $\begin{array}{c}\text { Name of the Varieties } \\
\text { (Treatments) }\end{array}$ & Ca (\%) & Mg (\%) & $\mathrm{N} \mathrm{( \% )}$ & $\mathrm{Cu}(\mathrm{ppm})$ & $\mathrm{Fe}(\mathrm{ppm})$ & $\mathrm{Zn}(\mathrm{ppm})$ \\
\hline BARI Sarisha-15 & $2.15 \mathrm{c}$ & $0.74 \mathrm{a}$ & $4.48 \mathrm{c}$ & $13.40 \mathrm{a}$ & $170.30 \mathrm{a}$ & $51.45 \mathrm{~b}$ \\
BARI Sarisha-16 & $2.52 \mathrm{ab}$ & $0.74 \mathrm{a}$ & $4.26 \mathrm{c}$ & $13.26 \mathrm{a}$ & $75.70 \mathrm{e}$ & $66.80 \mathrm{a}$ \\
BARI Sarisha-17 & $1.10 \mathrm{~d}$ & $0.64 \mathrm{a}$ & $3.66 \mathrm{~d}$ & $6.18 \mathrm{c}$ & $100.70 \mathrm{~d}$ & $51.91 \mathrm{~b}$ \\
\hline LSD (0.05) & 0.1409 & 0.1286 & 1.661 & 1.226 & 6.084 & 0.7277 \\
CV (\%) & $3.54 \%$ & $6.96 \%$ & $3.10 \%$ & $5.90 \%$ & $2.77 \%$ & $0.71 \%$ \\
\hline
\end{tabular}

Figure in a column followed by a common letter do not differ significantly at $5 \%$ level of DMRT

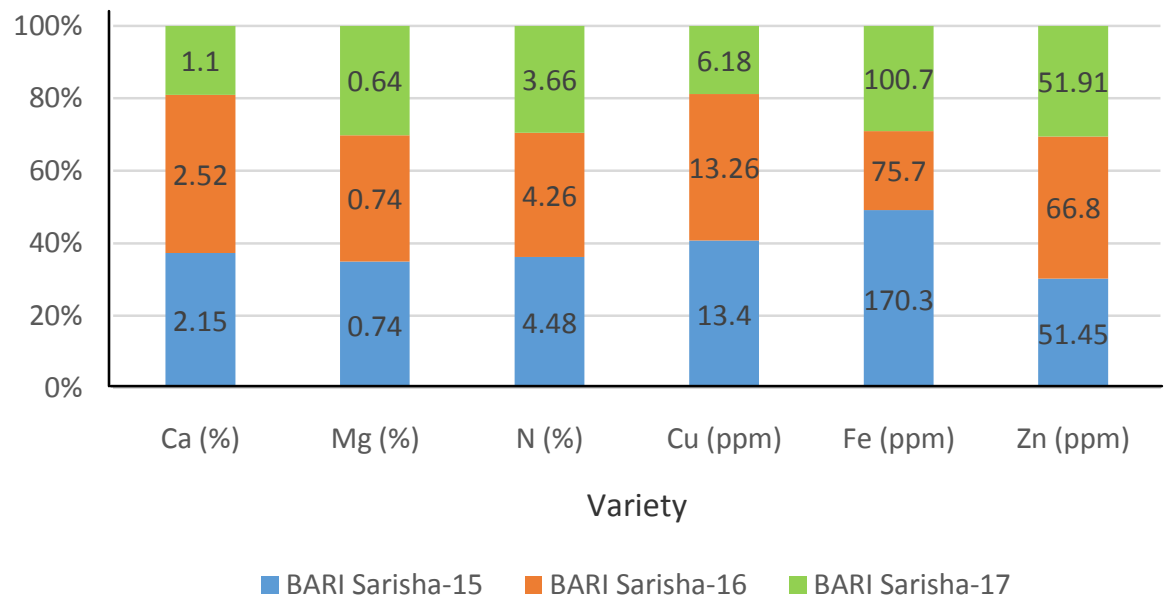

Fig. 6. Proximate analysis of mineral content of the different mustard oilseed varieties. 


\section{Gross energy}

Significantly the highest amount of energy from carbohydrate found in BARI Sarisha-17 $(75.41 \mathrm{kcal} / \mathrm{g})$, followed by BARI Sarisha-16 (56.20 kcal/g), BARI Sarisha-15 (54.92) (Table 7). The highest energy from protein observed from BARI Sarisha-15 $(112.00 \mathrm{kca} / \mathrm{g})$; whereas the lowest amount of energy from protein observed from BARI Sarisha-16 $(90.27 \mathrm{kcal} / \mathrm{g})$. The highest amount of energy from fat was observed in BARI Sarisha-17 (377.80 kcal/g), significantly same amount of energy obtained from BARI Sarisha-15 $(376.60 \mathrm{kcal} / \mathrm{g})$. The study found that Gross energy of different varieties of mustard ranged from $531.20 \mathrm{kcal} / \mathrm{g}$ to $543.6 \mathrm{kcal} / \mathrm{g}$. The highest amount of gross energy found from BARI Sarisha-15 $(543.60 \mathrm{kcal} / \mathrm{g})$; while lowest amount of gross energy recorded from BARI Sarisha-16 $(531.20 \mathrm{kcal} / \mathrm{g})$. Our studies reports were supported by the reports of Chowdhury et al., (2015), Hossain et al., (2015).

Table 7. Proximate analysis of gross energy from carbohydrates, proteins and oils of the different varieties of oilseed

\begin{tabular}{c|c|c|c|c}
\hline $\begin{array}{c}\text { Name of the Varieties } \\
\text { (Treatments) }\end{array}$ & $\begin{array}{c}\text { Energy from } \\
\text { Carbohydrate } \\
(\mathrm{kcal} / \mathrm{g})\end{array}$ & $\begin{array}{c}\text { Energy from } \\
\text { Protein } \\
(\mathrm{kcal} / \mathrm{g})\end{array}$ & $\begin{array}{c}\text { Energy from } \\
\text { Oil } \\
(\mathrm{kcal} / \mathrm{g})\end{array}$ & $\begin{array}{c}\text { Total Energy } \\
(\mathrm{kcal} / \mathrm{g})\end{array}$ \\
\hline BARI Sarisha-15 & $54.92 \mathrm{~b}$ & $112.00 \mathrm{c}$ & $376.60 \mathrm{c}$ & $543.6 \mathrm{~d}$ \\
BARI Sarisha-16 & $56.20 \mathrm{~b}$ & $106.40 \mathrm{c}$ & $368.50 \mathrm{~d}$ & $531.2 \mathrm{e}$ \\
BARI Sarisha-17 & $75.41 \mathrm{a}$ & $90.27 \mathrm{~d}$ & $377.80 \mathrm{c}$ & $543.5 \mathrm{~d}$ \\
\hline LSD (0.05) & 7.811 & 6.445 & 1.554 & 1.549 \\
CV (\%) & $10.10 \%$ & $3.10 \%$ & $0.21 \%$ & 0.15 \\
\hline
\end{tabular}

Figure in a column followed by a common letter do not differ significantly at $5 \%$ level by DMRT

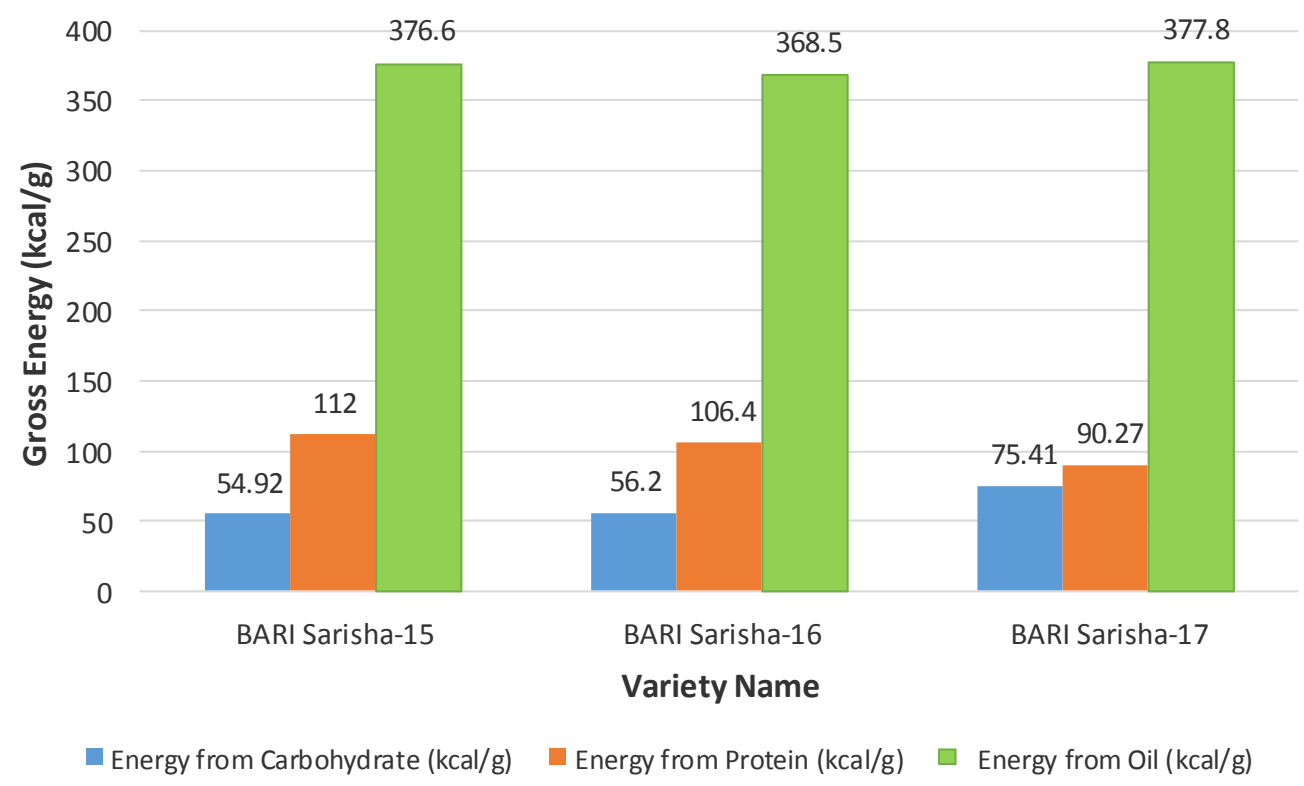

Fig. 7. Gross Energy of the different oilseed varieties

\section{Conclusion}

The physicochemical characteristics of three varieties of mustard oilseed were analyzed. Among those mustard varieties BARI Sarisha-17 contained highest amount of oil, saponification value, iodine value, carbohydrate contain and highest amount of total unsaturated fatty acid (TUSFA). It was observed that highest amount of gross energy found from BARI Sarisha-15 and it was also found that highest amounts protein, $\mathrm{Mg}, \mathrm{N}, \mathrm{Cu}, \mathrm{Fe}$ and highest amount of total saturated fatty acid (TSFA). All mustard varieties contained good amount of erucic acid. BARI Sarisha-16 contained highest amount of $\mathrm{Ca}$ and $\mathrm{Zn}$. It indicates that the BARI Sarisha-15 is a good candidate of most of the nutrient containing oil seed. 
Farmers are cultivating different varieties of mustard in their field for the consumption oil and oilcake as food, feed and fertilizer. BARI Sarisha-15, BARI Sarisha-16, and BARI Sarisha-17 are grown in large scale as they contained the fair amount of nutrient contents.

\section{Acknowledgements}

The Oilseeds Research Centre of BARI, Joydebpur, Gazipur, Bangladesh is gratefully acknowledged for their kind cooperation regarding the provide laboratory facilities for biochemical analysis of the mustard varieties and the supply the varieties seeds of Brassica spp. I would like to gratefully acknowledged Biochemistry laboratory of the Department of Biochemistry, Sher-e-Bangla Agricultural University, Dhaka, Bangladesh for financial support of our research work.

\section{References}

Ajala, A.S., and Adeleke, S.A. 2014. Effect of drying temperatures on physicochemical properties and oil yield of African star apple (Chrysophyllum alibidum) seeds. G.J. E.D.T., 3(3): 12-16.

Abul-Fadl, M.M., El-Badry, N. and Ammar, M.S. 2011. Nutritional and chemical evaluation for two different varieties of mustard seeds, World Appl. Sci. J., 15(9): 1225-1233.

Andrahennadi, C.P., Weerasena, L.A. and Aberyrantne, M.D.R.S. 1991. Evaluation of brown mustard germplasms in Srilanka. Cruciferae Newslett., 14(15): 62-63.

AOAC. 2010. Official methods of analysis. Association of official analytical chemists, Washington, DC.

Appelqvist, L.A. and Ohlson. 1992. Rapeseed. Elsevier Publishing Co., London NY. 37 pp.

Appelqvist, L.A. 1980. Fatty acid composition of the different varieties of Brassica seed oils. J. Am. Oil Chemt. Soc., 48(2): 852-853.

Aremu, M.O., Olaofe, O., and Akintayo, E.T. 2006. Chemical composition and physicochemical characteristics of two varieties of bambara groundnut (Vigna subterrenea) flours. J. Applied Sciences. 6(9): 1900-1903.

Arif, M., Nasiruddin, Masood, T. and Shah, S.S. 2012. Evaluation of oil seeds for their potential nutrients. ARPN J. Agri. and Bio. Sci., 7(9): 730-734.

Asibuo, J.Y., Akromah, R., Safo, K.S., Dapaah, A., Kofi, H., Dapaah, O., Seth. and Agyeman, A. 2008. Chemical composition of groundnut, Arachishypogaea (L) landraces. Afr. J. Biotechnol., 7(13): 2203-2208.

Ayoola, P. B., Adeyeye, A. and Onawumi, O.O. 2012. Chemical evaluation of food value of groundnut (Arachihypogaea) seeds. American J. Food and Nutri., 36: 2157-1317.

Banga, R.S., Dhawan, K. and Singh, D. 2013. Quality and yield of Indian mustard genotypes as influenced by different fertility levels. Oilseeds Section. Department of Plant Breeding, CCS Haryana Agricultural University, Hisar, India.

Bachheti, R.K., Rai, I., Joshi, A. and Rana, V. 2012. Physico-chemical study of seed oil of Prunusarmeniaca L. grown in Garhwal region (India) and its comparison with some conventional food oils. IFRJ., 19(2): 577-581.

BARI. 2001. Biochemical report on oilseeds. Oilseed Research Centre, Joydebpur, Gazipur.

Bhowmik, T.P. 2003. Oilseed Brassicas (constrain and their management). Principle Scientist (Retd.), Division of Mycology and pathology. Indian Agricultural Research Institute, New Delhi, India.

Biochemical report on oilseeds. Oilseed research center, Joydebpur, Gazipur.

Biswas, K.P. 1989. Performance evaluation of $14^{\text {th }}$ genotype of oleiferous Brassica. Proceeding of the $4^{\text {th }}$ Annual Scientific Conference, Bangladesh, 70 pp.

Chauhan, J.S. and Kumar, S. 2011. Assessment of oil and seed meal quality parameters of rapeseed mustard group of crops. Indian J. Agricul. Sci., 81: 140-144.

Chowdhury, M. F. N., Hossain, M. D., Hosen, M. and Rahman, M. S. 2015. Comparative study on chemical composition of five varieties of groundnut (Arachishypogaea). World J. Agric. Sci., 11(5): 247-254.

Chowdhury, M.F.N., Ahmed, K.U., Hosen, M., Paul, R.K. and Bhattacharjya, D.K. 2014. Evaluation of grain weight, moisture, dry matter, oil cake, $\beta$-carotene, oil constant and aflatoxin content of different varieties and advanced lines of mustard and rapeseed. IOSR-JAVS., 7(6): 34-39.

Chowdhury, M.F.N., Ahmed, K.U, Nuruddin, M.M. and Hosen, M. 2010. Study on fatty acid composition, oil and protein of different varieties and advanced lines of mustard and rapeseeds. Bangladesh Res. Pub. J., 4(1): 7.

Chowdhury, L.B. and Prasad, B. 1987. Genetic variation and heritability of quantitative characters in Indian mustard. Indian J. Agric. Sci., 38(5): 820-825.

Durrani, F.R., and Khalil, I.A. 1990. Chemical composition of Brassica oilseed meal. Pakistan. J. Sci. Ind. Res., 33: 39-41.

Gadei, G., Gaceu, L., and Gruia, R. 2012. Preliminary research regarding the impact of mustard flour addition in bread. Proceeding of International Conference on New Research in Food and Tourism, Bioatlas, Transylvania University of Brasov, Romania. 8(1): 135-139.

Gopalan, C., Rama Sastri, B.V. and Balasubraminian, S.C. 1981. Nutritive value of Indian foods. National institute of nutrition. ICMR, Hyderabad. India.

Hussain, R., Hussain, A., Asadullah., Sattar, S., Zeb, M., Hussain, A. and Nafees, M. 2015. Physico-chemical Properties and Assessment of Edible Oil Potential of Peanuts Grown in Kurram Agency, Parachinar. Pak. J. Anal. Environ. Chem., 16(1): 45-51. 
Idouraine, A., Kohlhepp, E.A., and Weber, C.W. 1996. Nutrient constituents from eight lines of naked seed squash (Cucurbitapepo L.). J. Agric. \& Food Chem., 44(3): 721-724.

Ingale, S. and. Shrivastava, S. K. 2011. Nutritional study of new variety of groundnut (Arachishypogaea L.) JL-24 seeds. Afr. J. Food Sci., 5(8): 490-498.

Josefson, E. 1988. Chemistry of the oil Industry. Indian J. Plant Physiology. 2(4): 250-251.

Kaul, A.K. and Das, M.L. 1986. Oilseeds in Bangladesh. Winrock International. Bangladesh Agricultural Research Council, Dhaka.

Khan, A., Sankhyan, P. and Kumar, S. 2013. Biochemical characterization of mustard oil (Brassica campestris L.) with special reference to its fatty acid composition. Asian J. of Adv. Basic Sci., 1(1): 1-9.

Mandal, S., Yadav, S., Singh, R., Begum, G., Suneja, P. and Singh, M. 2002. Correlation studies on oil content and fatty acid profile of some Cruciferous species. Genet. Res. Crop. Evol., 49: 551-556.

Mubashir, W., Bakshi, H., Ahmad, N., bhat and waheed-u-zaman. 2012. Effects of seed borne mycoflora on sugar, oil and fatty acid composition of three varieties of mustard (Brassica compestris) viz, basanti, kalasona, kaveri ak-47. Int. J. Pharm. Bio. Sci., 3(4): 421-428.

Mirza, M., Sirazul, H. Ullah, M.A. and Awwal, A. 1998. Variation of seed weight, oil and fatty acid composition in linseed oil. Bangladesh J. Agril. Res., 23(2): 307-314.

Mahmud, A., N., Hasan, M., Hossain, M. and Minar, M. 2012. Proximate composition of fish feed ingredients available in Lakshmipur region, Bangladesh. American-Eurasian J. Agric. \& Environ. Sci., 12(5): 556-560.

Moser, B. R., Shah, S.N., Winkler, J. K., Vaughn, S.F. and Evangelista, R.L. 2009. Composition and physical properties of cress (Lepidium sativum L.) and field pennycress (Thlaspiarvense L.) oils. Ind. Crops Prod., 30(2): 199-205.

Mondal, M.R.I. and Wahhab, M.A. 2001. Production technology of oilseeds. Oilseed Res. Laboratory, Bangladesh Agril. Res. Inst. Joydebpur, Gazipur, 6-24pp.

Martin, G. and Adre, E. 1995. Bulletin. Chem. Soc. France., 7: 217-225.

Novoselov, M.A., Sahai, V.N., S.H. and Mondal, M. 1997. Oil content in different oilseed varieties of Bangladesh. Indian J. Agric. Res., 22: 7-10.

Onimawo, I.A., Momoh, A.H. and Usman A., 1998. Proximate composition and functional properties of four cultivars of bambara groundnut (Voandzeia subterranea). Plant Foods Hum. Nutr., 53: 153-158.

Osborne, O. R. and Vooget P. 1978. Calculation of calorific value in the analysis of nutrients in roots, Academic Press New York: 239-244.

Pathak, R.K., Sharma, M.K. and Tripathi, R.D. 1973. Quality Studies in some cruciferous oilseeds. Indian J. Agric. Res., 7(2): 99-103.

Prapakornwiriya, N. and Diosady, L.L. 2004. Isolation of yellow mustard proteins by a microfiltration-based process. Int. J. Appl. Sci. Eng., 2(2): 127-135.

Raghuramula, N., Madhavan, N.K. and Kalyanasundaram, S. 2003. A Manual of laboratory techniques. National Institute of Nutrition, Indian Council of Medical Research, Hyderabad, India: 56-58.

Ranganna, S. 1986. Handbook of analysis and quality control for fruit and vegetable production, $2^{\text {nd }}$ ed, chapter 1 . New Delhi, The McGraw Hill publishing company limited.

Rathore, P.S. 1999-2000. Techniques and Management of field crop production. Rajasthan Agricultural University, Published by Agro bios India, Chopasani Road, Jodhpur.

Richet, H., Raget, S. and Raquot, C. 1987. Chemical characteristics of oil. ITERG., 4: 24-25.

Sarker, A.K., Saha, D, Hasina Begum, H., Zaman, A. and Rahman, M.M. (2015). Comparison of cake compositions, pepsin digestibility and amino acids concentration of proteins isolated from black mustard and yellow mustard cakes. AMB Express, 2015(5): 22.

Sarwar, M., Ahmad, N., Siddiqui, Q. H., Ali, A., and Tofique, M. 2004. Genotypic response in canola (Brassica species) against aphid (Aphidae: Homoptera) attack. Nucleus, 41(1-4): 87-82.

Sarwar, M., Ahmad, N., Khan, G.Z., and Tofique, M. 2009. Varietals resistance and susceptibility in mustard (Brassica campestris L.) genotypes against aphid Myzuspersicae (Sulzer) (Homoptera: Aphididae). Nucleus, 46(4): 507-512.

Sengupta, K. and Das, P.K. 2003. Cultivated annual oilseeds crops of India. Department of Agriculture, Govt of west Bengal, Published by Parthasankar Basu, 206 Bidhansarani, Kolkata, India.

Siavash, B., Karaptian, J. and Zare. S. 2005. Studying on lipid content and fatty acids in some varieties of colza (Brassica napus). J. Pajuhesh \& Sazandegi., 67: 95-101.

Siddiqui, M.H. and Fizor, M. 2004. Physiomorphological analysis of rapeseed mustard cultivars. Ind. J. Plant Physiol., 9(3): $283-284$.

Sosulski, F.W., and Bakal. 1991. Quality studies in some cruciferous oil seeds. Indian J. Agric. Res., 7(2): 99-703.

Stuchlik, M., and Zác, S. 2002. Vegetable lipids as components of functional foods. Biomed. Papers, 146(2): 3-10.

Thiex, N. J., Anderson, S., Gildemeister, B. 2003. Crude fat, diethyl ether extraction, in feed, cereal grain, and forage (Randall/soxtec/submersion method): collaborative study. J. AOAC International, 86(5): 888-898.

Uppstrom, B., and Johansson, S.A. 1978. Methods for determination of fatty acids applied to a breeding program. Proceedings of $5^{\text {th }}$ international rapeseed conference, Malmo, Sweden, 1: 140-144.

Vijay, K., Yadav and Neel, A.M. 1992. Oil and glucosinolate contents in Indian rapeseed and mustard varieties. Indian J. Agric., 21(2): 15-20. 